Law and Literature 



\section{Law and Literature}

TH I R D E D I T I O N

Richard A. Posner

Harvard University Press

Cambridge, Massachusetts · London, England 
Copyright (C) 1988, 1998, 2009 by the President and Fellows of Harvard College

All rights reserved

Printed in the United States of America

Excerpts from "Easter 1916," "The Second Coming," "The Wild Swans at Coole," and "Leda and the Swan" by William Butler Yeats are reprinted with the permission of Simon \& Schuster from The Collected Works of W. B. Yeats, Volume 1: The Poems, Revised and edited by Richard J. Finneran, copyright 1919, 1924 and 1928 by Macmillan Publishing Company, renewed 1947 and 1952 by Bertha Georgie Yeats and 1956 by Georgie Yeats; and by permission of A. P. Watt Ltd. on behalf of Michael Yeats.

Excerpts from "The Waste Land" and "Little Gidding" by T. S. Eliot are reprinted from T. S. Eliot, Collected Poems 19o9-1962, copyright 1936 by Harcourt Brace \& Company, copyright (C) 1964, 1963 by T. S. Eliot, and Four Quartets, copyright 1943 by T. S. Eliot and renewed 1971 by Esme Valerie Eliot, by permission of Faber and Faber Ltd. and Harcourt Brace \& Company.

The excerpt from The Sweeniad by Victor Purcell is reprinted by permission of Routledge Ltd.

\section{Library of Congress Cataloging-in-Publication Data}

Posner, Richard A.

Law and literature / Richard A. Posner.-3rd ed.

$$
\text { p. } \mathrm{cm} \text {. }
$$

Includes bibliographical references and index.

ISBN 978-0-674-03246-o (alk. paper)

1. Law in literature. 2. Law and literature. 3. Legal stories-History and criticism.

I. Title.

PN56.L33P67 2009

$809^{\prime} \cdot 933554-$ dc22 2008035602 


\section{For Charlene}


